\title{
IN MEMORIAM: \\ DONALD V. SMILEY (1921-1990)
}

Donald Smiley, a member of the Advisory Board of the Centre for Constitutional Studies, died on 28 April 1990, in Toronto. At the time of his death he was a Distinguished Research Professor Emeritus at York University in Toronto and was widely recognized as one of Canada's pre-eminent political scientists. During his career he had held faculty positions at Queen's University (1954-55), the University of British Columbia (1959-70), the University of Toronto (1970-76), and York University (1976-90). He was an alumnus of the University of Alberta, and to the regret of his many friends, Don did not live to accept the honourary degree that was to be conferred on him by his Alma Mater in June of 1990.

For over three decades Don Smiley was one of Canada's leading scholars in the field of constitutional politics. His many textbooks, monographs, essays, scholarly and popular articles and commentaries made an enormous contribution to our understanding of the "federal condition" of Canada (to use the title of one of his books). He was also a staunch advocate of the liberal ideal and an active defender of civil liberties.

In 1988, political scientists from across Canada, many of whom were proud to label themselves "Smiley's people", celebrated Don Smiley's lifetime of achievement by holding a conference in his honour. The papers of that conference were subsequently published as a book, Federalism and Political Community: Essays in Honour of Donald Smiley (edited by David P. Shugarman and Reg Whitaker and published by Broadview Press, 1989). The editors in their introduction captured the essence of Don Smiley's impact upon his colleagues with the following words:

Underlying Don Smiley's long years of scholarship and writing is a deep commitment to the standards and traditions of the scholarly community, both in Canada and abroad, and a deep, even passionate commitment to the political community of the country in which he was born and to which he has devoted his many talents and energies over the years. In both cases, there is the same strong faith in the value of freedom: free institutions and free people pursuing their goals without arbitrary interference from either the state or powerful interests, but with maximum tolerance for the diversity of goals and beliefs among fellow scholars and citizens. The liberal ideal is always fragile and difficult to realize but Don Smiley in his life and work has exemplified it.

It is not only in his work but in his person that Don Smiley has left his mark on a generation. As a teacher and as a colleague he will be long remembered. Whether conducting a graduate seminar, participating in one of the innumerable scholarly conferences to which he has been devoted, or simply engaging with seemingly inexhaustible gusto in discussions about politics and life, he has enlivened and stimulated all with whom he has come in contact.

With Don's death, the Centre for Constitutional Studies has lost a good friend and advisor, and his many colleagues, of which I was fortunate to be one, have lost a close and dear friend. 